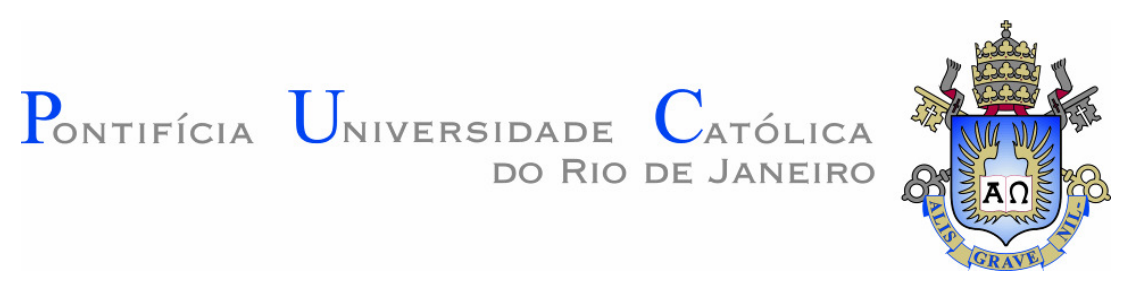

Rodrigo Jose Coelho Pereira

Análise de Correlação entre Alterações na Cobertura
Vegetal e o Comportamento Hidrológico na Bacia
Hidrográfica do Rio Cachoeira - RJ

Dissertação de Mestrado

Dissertação apresentada como requisito parcial para obtenção do grau de Mestre pelo Programa de Pós-Graduação em Engenharia Urbana e Ambiental da PUC-Rio.

Orientador: Prof. Rogério Ribeiro de Oliveira 


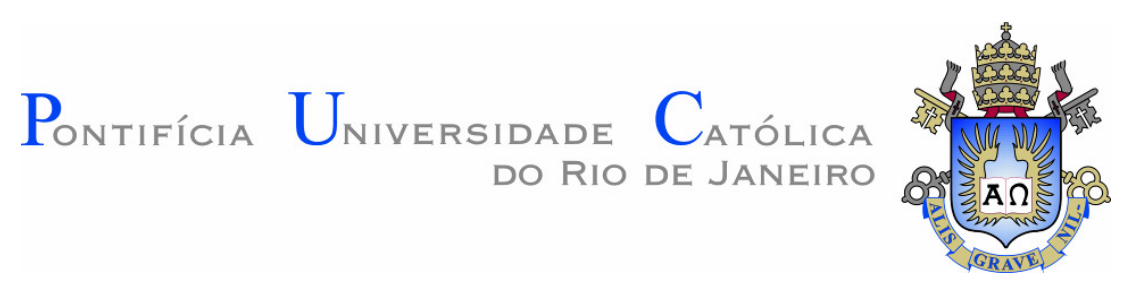

Rodrigo Jose Coelho Pereira

\title{
Análise de Correlação entre Alterações na Cobertura Vegetal e o Comportamento Hidrológico na Bacia Hidrográfica do Rio Cachoeira - RJ
}

\begin{abstract}
Dissertação apresentada como requisito parcial para obtenção do grau de Mestre pelo Programa de PósGraduação em Engenharia Urbana e Ambiental da PUC-Rio. Aprovada pela Comissão Examinadora abaixo assinada.
\end{abstract}

Prof. Rogério Ribeiro de Oliveira

Orientador

Departamento de Geografia - PUC-Rio

Prof. Luiz Felipe Guanaes Rego Departamento de Geografia - PUC-Rio

Prof. Anderson Mululo Sato

UFRJ

Prof. José Eugenio Leal

Coordenador Setorial do Centro

Técnico Científico - PUC-Rio

Rio de Janeiro, 15 de Agosto de 2012. 
Todos os direitos reservados. É proibida a reprodução total ou parcial do trabalho sem autorização do autor, do orientador e da universidade.

\section{Rodrigo Jose Coelho Pereira}

Graduado em Engenharia Civil, com ênfase na área de Recursos Hídricos e Meio Ambiente, pela Universidade Federal do Rio de Janeiro (2009/1). Atualmente é engenheiro de projetos atuando principalmente nas áreas de Hidrologia, Modelagem Hidrológica, Geoprocessamento e Obras Hidráulicas.

Ficha Catalográfica

Pereira, Rodrigo Jose Coelho

Análise de Correlação entre Alterações na Cobertura Vegetal e o Comportamento Hidrológico na Bacia Hidrográfica do Rio Cachoeira - RJ / Rodrigo Jose Coelho Pereira ; orientador: Rogério Ribeiro de Oliveira. -2012.

86 f. : il. (color.) ; $30 \mathrm{~cm}$

Dissertação (mestrado) - Pontifícia Universidade Católica do Rio de Janeiro, Departamento de Engenharia Civil, 2012.

Inclui bibliografia

1. Engenharia civil - Teses. 2. Engenharia urbana e ambiental. 3. Balanço hídrico. 4. Hidrologia florestal. 5. Evapotranspiração real. 6. Geoprocessamento. 7. Sensoriamento remoto. I. Oliveira, Rogério Ribeiro de. II. Pontifícia Universidade Católica do Rio de Janeiro. Departamento de Engenharia Civil. Programa de PósGraduação em Engenharia Urbana e Ambiental. III. Título. 


\section{Agradecimentos}

Gostaria de agradecer primeiramente a minha família, em especial meus pais, Antonio e Vera, e meu avô, Arnaldo, por todo o apoio, compreensão e paciência concedida, não apenas durante o desenvolvimento do mestrado, mas ao longo dos meus 28 anos.

A minha namorada, Danyelle, pelo carinho, amor e incentivo, sempre me ajudando a passar por tudo.

Aos colegas de mestrado, que compartilharam comigo momentos importantes, tanto os difíceis quanto os de alegria, os quais me deixam lembranças inesquecíveis.

Ao meu professor e orientador, Rogério Ribeiro de Oliveira, pela oportunidade oferecida, suporte, críticas e sugestões fundamentais para a conclusão do estudo da presente dissertação e aprendizado.

Agradeço também àqueles aqui não mencionados, mas que guardo em meu coração, pela ajuda, pela amizade, pelo companheirismo, pelos ensinamentos e por compartilharem parte de suas vidas comigo. 


\section{Resumo}

Pereira, Rodrigo Jose Coelho; Oliveira, Rogério Ribeiro de (Orientador). Análise de Correlação entre Alterações na Cobertura Vegetal e o Comportamento Hidrológico na Bacia Hidrográfica do Rio Cachoeira

- RJ. Rio de Janeiro, 2012. 86p. Dissertação de Mestrado

Departamento de Engenharia Civil, Pontifícia Universidade Católica do Rio de Janeiro.

O presente trabalho teve como unidade de estudo a bacia hidrográfica do rio Cachoeira, localizada na vertente sul do Maciço da Tijuca, município do Rio de Janeiro. O objetivo geral do estudo foi analisar os efeitos das alterações na cobertura vegetal dessa bacia sobre seu comportamento hidrológico. As componentes hidrológicas selecionadas para análise foram a evapotranspiração real e a vazão média na exutória da bacia. Através do método do balanço hídrico de Thornthwaite e Mather, aplicado de forma sequencial, foi estimada uma série mensal de evapotranspirações reais da bacia. Foram utilizados nesse método de balanço hídrico dados de temperaturas médias do ar e totais precipitados na região. A série de vazões médias na exutória da bacia foi obtida utilizando-se como referência as estações fluviométricas Capela Mayrink e Itanhangá, ambas situadas no interior da bacia. Por meio de tecnologias de geoprocessamento e sensoriamento remoto foram mapeadas dez imagens do satélite Landsat-5/TM, estimando-se assim as alterações ocorridas na cobertura vegetal da bacia. Finalmente buscou-se estabelecer correlações entre as variações da cobertura vegetal e das componentes hidrológicas selecionadas. O resultado obtido para a evapotranspiração real foi satisfatório, indicando uma relação direta com a dinâmica da cobertura da bacia. Entretanto não foi possível estabelecer para a vazão média uma correlação de qualidade semelhante. Através desse estudo adquiriu-se um melhor entendimento sobre a influência da variação da cobertura vegetal no comportamento hidrológico da bacia hidrográfica do rio Cachoeira.

\section{Palavras-chave}

Balanço hídrico; hidrologia florestal; evapotranspiração real; geoprocessamento; sensoriamento remoto. 


\section{Abstract}

Pereira, Rodrigo Jose Coelho; Oliveira, Rogério Ribeiro de (Advisor). Correlation Analysis between Land Cover Changes and Hydrologic Behavior in River Cachoeira Watershed - RJ. Rio de Janeiro, 2012. 86p. MSc. Dissertation - Departamento de Engenharia Civil, Pontifícia Universidade Católica do Rio de Janeiro.

The present work had as unit of study the Cachoeira river watershed, located on the southern slope of the Tijuca Massif, city of Rio de Janeiro, between the parallels $22^{\circ} 56^{\prime}$ and $23^{\circ} 00^{\prime}$ of south latitude and the meridians $43^{\circ} 15^{\prime}$ and $43^{\circ} 19^{\prime}$ of west longitude. The watershed has a triangular shape, covering a drainage area of $21,7 \mathrm{~km}^{2}$.

The general objective of the study was to analyze the effects of land cover changes on hydrological processes of the Cachoeira river watershed. The hydrological components selected for analysis were the real evapotranspiration and the mean flow at the exutory of the watershed. Through the Thornthwaite and Mather water balance method, applied sequentially to the period between 1997 and 2010, a monthly series of real evapotranspiration was established. The choice of this method was based on the compatibility of the data required by the method with the hydrometeorological available data.

Monthly series of average air temperatures and total precipitations was used to calculate the water balance of Thornthwaite and Mather. The average air temperature data were obtained from the pluviometric station Alto da Boa Vista, located around the watershed. In order to obtain a complete and consistent data series of average air temperatures, a correlation was established of these data with the data from the climatological station of the city of Rio de Janeiro. Through this correlation was possible to confirm the consistency of the series of air temperatures and fill any gaps from 1997 until the year 2010. In this period the monthly series of average air temperatures had a mean of $22,1{ }^{\circ} \mathrm{C}$, ranging from a maximum of $27,5{ }^{\circ} \mathrm{C}$ and a minimum of $17,8{ }^{\circ} \mathrm{C}$. The pluviometric data used as reference for the average rainfall over the Cachoeira river watershed, was recorded at the pluviometric station Capela Mayrink, located within the watershed. The consistency of this series has been verified before the other pluviometric stations around the watershed by the method of the double mass, 
which could confirm the consistency because no deviations were found in the precipitation behavior over time. The average annual precipitation over the watershed was $2.181 \mathrm{~mm}$.

The highest estimated values of real evapotranspiration were found in the rainy season, between December and March. The estimated average value of annual real evapotranspiration during the studied period was $1.056 \mathrm{~mm}$, ranging between $1.007 \mathrm{~mm}$ and $1166 \mathrm{~mm}$. This average value corresponds to approximately $50 \%$ of total annual precipitated, in other words, it is indicated that half of the precipitation over the watershed would return to the atmosphere by the processes of the hydrological cycle. Besides the real evapotranspiration, the water balance also provided an estimation of the water extract of the watershed, calculating components as water deficit, water surplus and soil water storage.

The mean monthly flow series at the exutory of the watershed was obtained by referencing the data recorded at the fluviometric stations Capela Mayrink and Itanhangá, both located within the watershed. The data from these stations have gone through a consistency analysis, where their fluviometric levels were verified together and their rating curves were elaborated to represent an adequate adjustment to their liquid discharge measurements. After the consistency analysis, the fluviometric levels data were transformed into flows, through the rating curves. The methodology adopted to generate the flow series at the exutory of the watershed consisted primarily in the extension of the flows series at Itanhangá station through correlation with the flows at Capela Mayrink station. Subsequently, the extended flow series at Itanhangá station was transferred to the exutory location by proportionality between drainage areas. Due to the lack of local data, it was not possible to obtain a mean monthly flow series without gaps.

The comparison of the flow data with the precipitation data, obtained for the Cachoeira river watershed, showed a coherent behavior over the years. The annual variation of rainfall in the watershed was accompanied by the flow.

It was possible to estimate the changes in land cover during the period from 1988 to 2010 using geoprocessing and remote sensing technologies, available at the extension Spatial Analyst Tool from the software ArcGIS 9.3. In order to obtain this data, a geographic information system was developed for the Cachoeira river watershed, composed by a digital terrain model, obtained from the Shuttle Radar Topography Mission (SRTM), and by ten digital images obtained 
from the satellite Landsat-5/TM, spaced in average every two years during the studied period.

The digital terrain model was used to generate the information grids of Flow direction and Flow accumulation. Through these grids, the watershed and the drainage areas of the fluviometric stations could be automatically delineated. The delimitation of the fluviometric stations drainage areas was done in order to verify the official areas mentioned in the inventory stations of the Brazilian National Water Agency. Although the calculated values did show differences in comparison with the official ones, they were used in the study, considering that the relative errors are minimized when using the same geographic basis.

Initially the application of digital processing techniques on satellite images consisted of a combination of bands 5, 4, 3, to form the color composite R, G, B. All images were georeferenced at the same control points in the UTM projection system, using the Datum WGS-84, Zone 23 South. Subsequently the images were classified using the supervised classification maximum likelihood. To characterize the dynamics of land cover over time, two thematic classes were chosen: Forest Area, which has forest cover and others natural features not modified by human activities and Non-Forest Area, which includes urbanized areas and most areas that original feature has been changed as a result of human activities and. The signature samples collected for each training were simple and spatially well distributed, within the region of the studied watershed.

Since the supervised classification was an automatic process, the thematic products generated showed errors, identified as isolated cells outside the context of the classes, which left the areas fragmented. In order to work around these errors and provide uniformity of the mapped classes a post-classification process was done on the images by applying a majority filter, which replaces isolated cells based on the majority of their contiguous neighboring cells. Even so, a small portion of the thematic products still showed classification errors, so they were manually edited to become more representative. Ten thematic maps of land cover for the Cachoeira river watershed were generated as products of these processes. The validation of each thematic map classification was verified through the confusion matrix. Considering that only two thematic classes with distinct characteristics were used, the performance of the confusion matrix was tendentious and insufficient to ensure the accuracy of the classification. In order 
to evaluate the quality of the thematic maps obtained, the thematic map generated for 2010 was compared with the official one, provided by the Municipal Secretariat of Environmental of Rio de Janeiro (SMAC). This comparison could validate the consistency of the thematic map of 2010, believing that the other thematic maps also represent an estimate of the land cover reality from past period.

The ten thematic maps could estimate the history of land cover changes on the Cachoeira river watershed. It was observed at the maps that there were changes in the shape of the occupation of the watershed, however, in accordance with the estimated percentages, the evolution of land cover in the watershed had a steady behavior over the years. The consecutive differences found did not exceed the order of $3 \%$.

Finally, correlations were established between the variation of the areas with forest coverage and the variation of the selected hydrological components. The result obtained at the real evapotranspiration correlation was satisfactory, which indicates a direct relationship between this hydrological component and the watershed land cover dynamic. However it was not possible to establish a correlation of similar quality with the mean flow.

This study could contribute as an exercise to aggregate knowledge about the influence of land cover on hydrological processes over time.

\section{Keywords}

Water balance; forest hydrology; real evapotranspiration; geoprocessing; remote sensing. 


\section{Sumário}

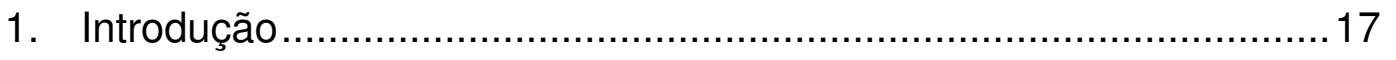

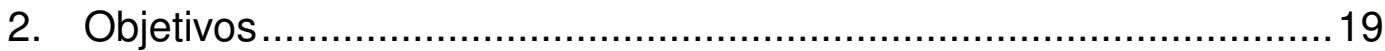

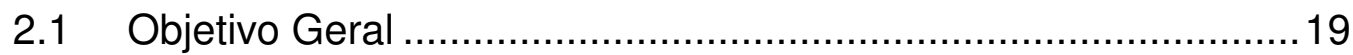

2.2 Objetivos Específicos ........................................................... 19

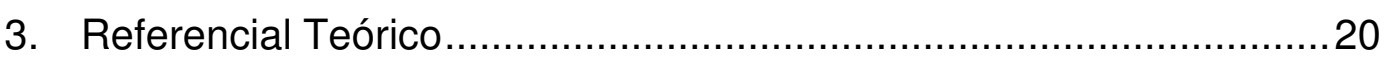

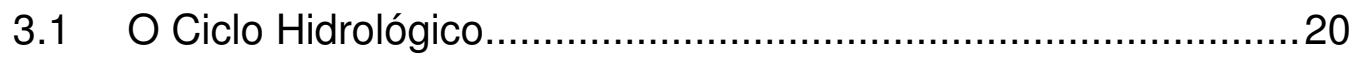

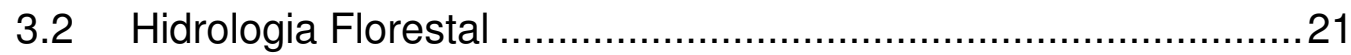

3.3 Estimativa da Evapotranspiração .............................................23

3.3.1 O Balanço Hídrico de Thornthwaite e Mather .......................24

3.4 Sistemas de Informação Geográfica e Geoprocessamento .........26

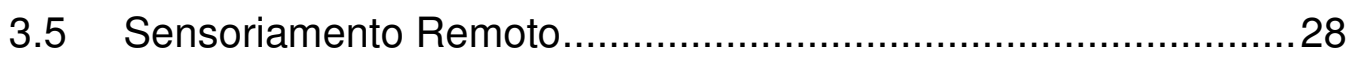

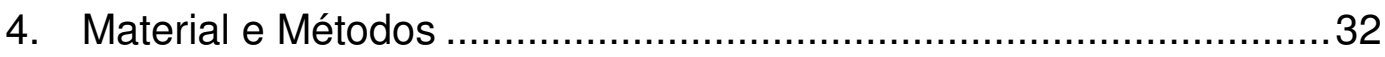

4.1 Caracterização da Bacia Hidrográfica de Estudo .........................32

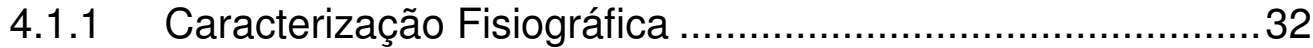

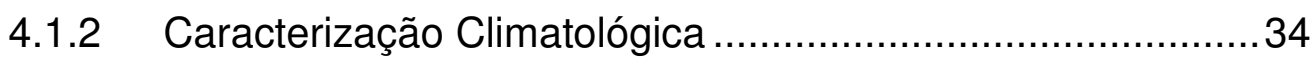

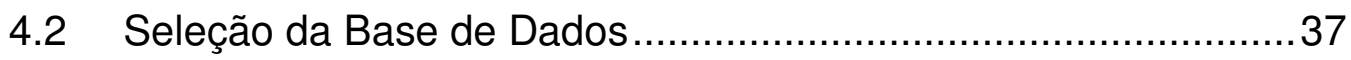

4.2.1 Seleção de Dados Geográficos ..........................................37

4.2.2 Seleção de Dados Hidrometeorológicos...............................38

4.2.3 Seleção de Dados de Satélite ............................................ 42

4.3 Tratamento da Base de Dados ................................................. 43

4.3.1 Tratamento dos Dados Geográficos ................................... 43

4.3.2 Tratamento dos Dados Hidrometeorológicos ....................... 45

4.3.3 Tratamento dos Dados de Satélite .....................................55

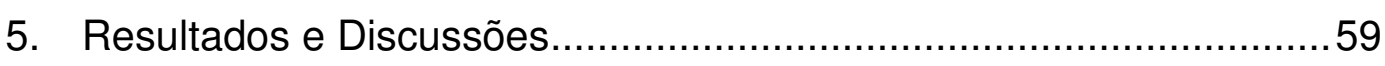

5.1 Comportamento Hidrológico da Bacia ........................................59

5.1.1 Análise da Relação Anual entre a Precipitação e a Vazão...59 
5.1.2 Estimativa da Evapotranspiração pelo Método do Balanço Hídrico de Thornthwaite e Mather. 60

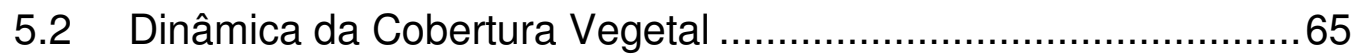

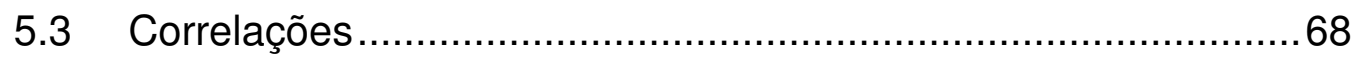

6. Conclusões e Recomendações ……………….............................. 71

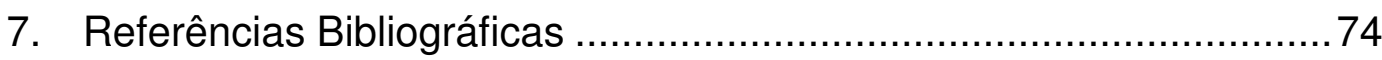

Apêndice A - Curvas Duplo-acumulativas das Estações

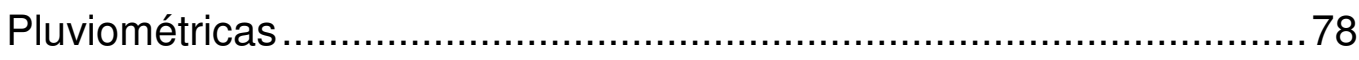

Apêndice B - Precipitações Totais Mensais na Bacia do Rio

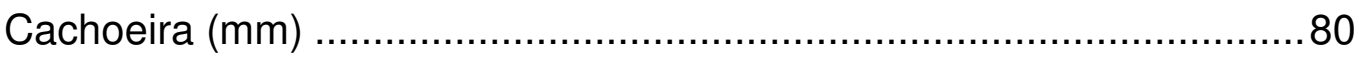

Apêndice C - Vazões Médias Mensais na Exutória da Bacia do Rio

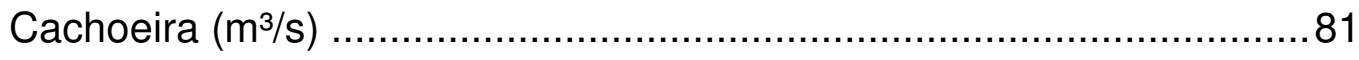

Apêndice D - Temperaturas Médias do Ar na Estação Alto da Boa

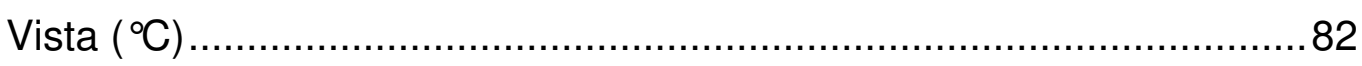

Apêndice E - Balanço Hídrico de Thornthwaite e Mather para a Bacia

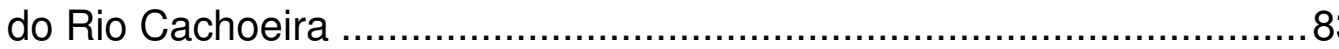




\section{Lista de Figuras}

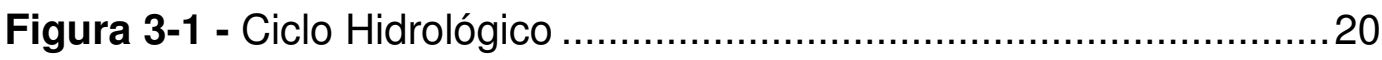

Figura 3-2 - Arquitetura de Sistemas de Informação Geográfica..............26

Figura 3-3 - Representação das Três Entidades do Modelo Vetorial ......27

Figura 3-4 - Representação das Três Entidades do Modelo Matricial .....27

Figura 3-5 - O Espectro Eletromagnético e suas Principais Regiões ......29

Figura 4-1 - Mapa de Localização da Bacia do Rio Cachoeira..................32

Figura 4-2 - Perfil Longitudinal do Rio Cachoeira ......................................3

Figura 4-3 - Características Climatológicas da Região - Temperaturas

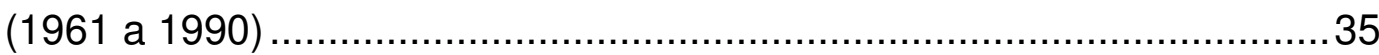

Figura 4-4 - Características Climatológicas da Região - Evaporação e

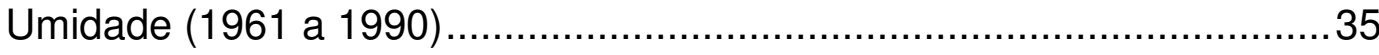

Figura 4-5 - Características Pluviométricas da Bacia do Rio Cachoeira

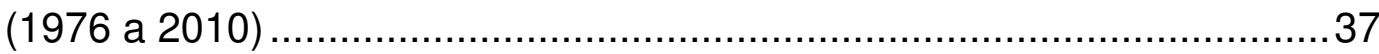

Figura 4-6 - Localização das Estações Hidrometeorológicas ................... 40

Figura 4-7 - Sequência de criação dos planos de informação................... 44

Figura 4-8 - Delimitação das Áreas de Drenagem dos Locais

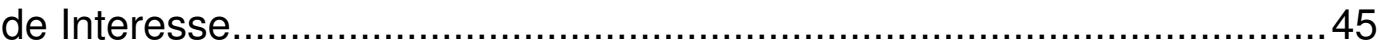

Figura 4-9 - Curva Duplo-acumulativa da Estação Pluviométrica

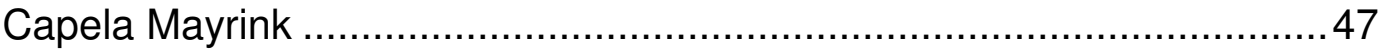

Figura 4-10 - Precipitação Total Mensal na Bacia do Rio Cachoeira ......48

Figura 4-11 - Comparação entre as leituras de régua médias diárias das estações

Figura 4-12 - Curva-chave do Rio Cachoeira na Estação

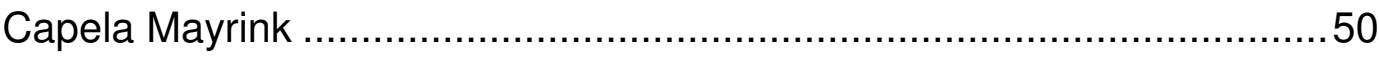

Figura 4-13 - Curva-chave do Rio Cachoeira na Estação Itanhangá .......51

Figura 4-14 - Correlação de Vazões Médias Mensais entre as

Estações Capela Mayrink e Itanhangá (abril/1976 a abril/1981) ..............52

Figura 4-15 - Vazões Médias Mensais na Exutória da Bacia do Rio Cachoeira.

Figura 4-16 - Correlação Mensal de Temperaturas Médias do Ar entre as Estações Rio de Janeiro e Alto da Boa Vista (fev/2003 a dez/2005)..53 
Figura 4-17 - Temperaturas Médias do Ar na Estação Alto da Boa

Vista

Figura 4-18 - Registro da Imagem de 2010 Corrigida

Geograficamente 56

Figura 5-1 - Comportamento Anual da Precipitação e da Vazão na Bacia

Figura 5-2 - Correlação Anual da Precipitação com a Vazão na Bacia ...60

Figura 5-3 - Precipitação Total Mensal e Temperatura Média do Ar na Bacia do Rio Cachoeira entre 1997 e 2010

Figura 5-4 - Extrato do Balanço Hídrico Mensal para o Período de 1997 a 2010

Figura 5-5 - Variação Mensal do Armazenamento de Água no Solo entre 1997 e 2010

Figura 5-6 - Evapotranspiração Potencial e Evapotranspiração Real, entre 1997 e 2010

Figura 5-7 - Variação da Evapotranspiração Real e da Vazão (1997 a 2010)

Figura 5-8 - Variação da Evapotranspiração Real e da Precipitação (1997 a 2010)

Figura 5-9 - Mapas de Cobertura Florestal na Bacia do Rio Cachoeira em Função das Classes "Área Florestal" e "Área Não Florestal" 66

Figura 5-10 - Quantificação do Mapeamento de Cobertura Florestal na Bacia do Rio Cachoeira

Figura 5-11 - Comparação dos Mapeamentos Temáticos de Cobertura Florestal - 2010

Figura 5-12 - Correlação entre a Variação da Porcentagem de Área Florestal e da Evapotranspiração Real Estimada na Bacia do Rio Cachoeira 69

Figura 5-13 - Correlação entre a Variação da Porcentagem de Área Florestal e da Vazão Média na Bacia do Rio Cachoeira 


\section{Lista de Tabelas}

Tabela 3-1 - Classificação sobre a mudança e uso do solo. 22

Tabela 3-2 - Características Espectrais e Espaciais do Sensor TM do Satélite Landsat-5

Tabela 3-3 - Principais características e aplicações das bandas do sensor TM do satélite Landsat-5 ........................................................ 31

Tabela 4-1 - Índices Fluviomorfológicos da Bacia do Rio Cachoeira ........33

Tabela 4-2 - Características Climatológicas da Região -

Temperaturas, Evaporação e Umidade (1961 a 1990)

Tabela 4-3 - Características Pluviométricas da Bacia do Rio

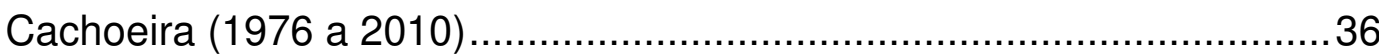

Tabela 4-4 - Dados Geográficos Selecionados........................................ 38

Tabela 4-5 - Estações Fluviométricas Selecionadas ................................39

Tabela 4-6 - Estações Pluviométricas Selecionadas ..................................39

Tabela 4-7 - Estação Climatológica Selecionada...................................... 39

Tabela 4-8 - Disponibilidade de Dados Fluviométricos ..............................41

Tabela 4-9 - Disponibilidade de Dados Pluviométricos.............................41

Tabela 4-10 - Disponibilidade de Dados Climatológicos ............................41

Tabela 4-11 - Áreas de Drenagem Calculadas nos Locais de Interesse . 45

Tabela 5-1 - Valores Anuais da Precipitação e da Vazão na Bacia ..........59

Tabela 5-2 - Evapotranspiração Real Mensal Estimada (1997 a 2010)...61

Tabela 5-3 - Quantificação do Mapeamento de Cobertura Florestal na Bacia do Rio Cachoeira 66

Tabela 5-4 - Variação da Porcentagem de Área Florestal e da Evapotranspiração Real Estimada na Bacia do Rio Cachoeira. 68

Tabela 5-5 - Variação da Porcentagem de Área Florestal e da Vazão Média na Bacia do Rio Cachoeira ....................................................... 70 


\section{Lista de Abreviaturas}

Agritempo Sistema de Monitoramento Agrometeorológico

ANA Agência Nacional de Águas

CPRM Companhia de Pesquisa de Recursos Minerais

DGI Divisão de Geração de Imagens do INPE

ESRI Environmental Systems Research Institute

GEORIO Instituto de Geotécnica do Município do Rio de Janeiro

Hidroweb Sistema de informações hidrológicas da ANA

IBGE Instituto Brasileiro de Geografia e Estatística

INEA Instituto Estadual de Ambiente

INMET Instituto Nacional de Meteorologia do Brasil

INPE Instituto Nacional de Pesquisas Espaciais

IPP-Rio Instituto Municipal de Urbanismo Pereira Passos

LabGis Laboratório de Geoprocessamento da PUC-Rio

MDT Modelo Digital do Terreno

SIG Sistema de Informação Geográfica

SMAC Secretaria Municipal de Meio Ambiente

SRTM Shuttle Radar Topography Mission

TM Thematic Mapper

UTM Universal Transverso de Mercator

WGS-84 World Geodetic System - 1984 


\section{Lista de Símbolos}

$\begin{array}{ll}\text { ARM } & \text { Armazenamento de água no solo }(\mathrm{mm}) \\ \text { CAD } & \text { Capacidade de água disponível no solo }(\mathrm{mm}) \\ \text { DEF } & \text { Deficiência hídrica }(\mathrm{mm}) \\ \text { ETP } & \text { Evapotranspiração potencial }(\mathrm{mm}) \\ \text { ETR } & \text { Evapotranspiração real }(\mathrm{mm}) \\ \text { EXC } & \text { Excedente hídrico }(\mathrm{mm}) \\ \mathrm{h}_{0} & \text { Leitura de régua correspondente ao zero da régua }(\mathrm{cm}) \\ \mathrm{i} & \text { índice de calor } \\ \mathrm{I}_{\mathrm{t}} & \text { Índice anual de eficiência de temperatura } \\ \mathrm{LR} & \text { Leitura de régua correspondente à vazão } \mathrm{Q}(\mathrm{cm}) \\ \mathrm{m} \text { e } \mathrm{n} & \text { Parâmetros de ajuste de curva-chave } \\ \mathrm{N} & \text { Fotoperíodo (h) } \\ \mathrm{ND} & \text { Número de dias no mês } \\ \mathrm{Q} & \text { Vazão (m³/s) } \\ \mathrm{R}^{2} & \text { Coeficiente de determinação } \\ \mathrm{T}_{\mathrm{méd}} & \left.\text { Temperatura média mensal do ar ( }{ }^{\circ} \mathrm{C}\right)\end{array}$

